\title{
A tradução de Zora Neale Hurston para o cânone antropológico: Práticas de extensão desde uma perspectiva feminista e interseccional ${ }^{1}$
}

\author{
Ana Gretel Echazú Böschemeier \\ gretigre@gmail.com \\ Universidade Federal de Rio Grande do Norte, Brasil
}

\begin{abstract}
Natalia Cabanillas
nataliacabanillas@unilab.edu.br

Universidade da Integração Internacional da Lusofonia Afro-Brasileira, Brasil
\end{abstract}

\section{Sandra S. F. Erickson sandra@ufrnet.br} Universidade Federal do Rio Grande do Norte, Brasil

\section{Victória Dias Barbosa victoriadias@ufrn.edu.br} Universidade Federal do Rio Grande do Norte, Brasil

\section{Fernanda Ferreira do Nascimento fernandafnascimentol@gmail.com https_//orcid.org/0000-0002-5967-3416 Universidade Federal do Rio Grande do Norte, Brasil}

\section{Mikaelle Thaisa da Costa} mikaellecosta@gmail.com Universidade Federal do Rio Grande do Norte, Brasil

\section{Fídias Cavalcanti Freire phidias1350@gmail.com}

Universidade Federal do Rio Grande do Norte, Brasil

\footnotetext{
1 Nesse texto apresentamos os resultados parciais do projeto de extensão PROEX-97661265 chamado RECânone, "oficina permanente de tradução, interpretação e legendado de materiais indígenas, afrodiaspóricos e latines", coordenado pela Professora Ana Gretel Echazú e cujo primeiro ciclo teve início entre julho e dezembro de 2019 na Universidade Federal de Rio Grande do Norte, Natal, Brasil.
} 


\title{
Resumo
}

Na nossa prática de pesquisa, ensino e extensão interligadas, nos valemos dos processos tradutórios como ferramenta para ampliar lugares de fala. Aqui discutimos os processos de leitura e tradução de alguns textos escolhidos de autoria de Zora Neale Hurston, antropóloga, ativista e artista afro-norte-americana dos anos 1930, que inspirou uma geração de pensadoras e escritoras negras vinculadas aos direitos humanos através da escrita de compilações folclóricas, ensaios autobiográficos, ficções etnográficas, contos, relatos e novelas. Nosso trabalho pretende contribuir para reivindicar o lugar de Hurston dentro das memórias da antropologia e da cultura. Na explicitação do processo tradutório, nos valemos das ferramentas teórico-metodológicas da interseccionalidade e da decolonialidade, questionando a solidez do cânone antropológico por meio da tradução cultural de vozes subalternizadas no diálogo entre espaços Sul-Sul.

Palavras-chave: Zora Hurston, tradução, extensão, interseccionalidade, antropologia.

\section{La traducción de Zora Neale Hurston al canon antropológico: prácticas} de extensión universitaria desde uma perspectiva feminista e interseccional

\section{Resumen}

En nuestra práctica de investigación, enseñanza y extensión interrelacionada, nos valemos de los procesos de traducción como herramienta para ampliar los lugares de enunciación. En este artículo se analizan los procesos de lectura y traducción de algunos textos elegidos escritos por Zora Neale Hurston, antropóloga, activista y artista afro-norteamericana de la década de 1930, que inspiró a una generación de pensadores y escritores negres en materia de derechos humanos mediante la redacción de compilaciones folklóricas, ensayos autobiográficos, ficciones etnográficas, cuentos, relatos y novelas. Orientada por Franz Boas en la Universidad de Columbia y colega de figuras antropológicas clave como Ruth Benedict y Margaret Mead, el camino de Hurston fue diferente: a pesar de ser una autora prolífica, crítica y muy original, la antropóloga murió en la pobreza y en el olvido de sus pares. Nuestro trabajo tiene como objetivo contribuir la demanda por el lugar de Hurston en las memorias de la antropología y la cultura. Para explicitar el proceso de traducción se utilizan las herramientas teórico-metodológicas de la interseccionalidad y la descolonialidad, cuestionando la solidez del canon antropológico a través de la traducción cultural de voces subalternizadas en el diálogo entre espacios Sur-Sur.

Palabras clave: Zora Hurston, traducción, extensión, interseccionalidad, antropología.

\section{Translating Zora Neale Hurston Into the Anthropological Canon: An Intersectional Feminist Approach to a Community Outreach Project}

\begin{abstract}
In our intertwined practice of research, teaching and community outreach, we make use of translation processes as a tool to expand situated narratives. Here we discuss the reading and translation processes of some selected texts written by Zora Neale Hurston, anthropologist, activist and afrodescendant artist of the 1930s born in the Us, who inspired a generation of Black Civil Rights thinkers and writers through the writing of folk compilations, autobiographical essays, ethnographic fictions, short stories, stories and novels. Supervised by Professor Franz Boas at Columbia University and a colleague of key anthropological figures, such as Ruth Benedict and Margaret Mead, Hurston's path was different: despite being a prolific, critical and highly original author, the anthropologist died in poverty and in the oblivion of her peers. Our work aims to claim Hurston's place within the canon of
\end{abstract}


anthropology and culture. In explaining the translation process, we make use of the theoretical-methodological tools of intersectionality and decoloniality, questioning the solidity of the anthropological canon through the cultural translation of subalternized voices in the dialogical South-South space.

Keywords: Zora Hurston, translation, extension, intersectionality, anthropology.

\section{La traduction de Zora Neale Hurston dans le canon anthropologique: pratiques d'extension dans une perspective féministe et intersectionnelle}

\section{Résumé}

Dans notre pratique de recherche scientifique, d'enseignement et d'extension interconnectée, nous faisons fort des processus de traduction comme outil pour étendre les lieux de parole. Nous discutons ici les processus de lecture et de traduction de quelques textes sélectionnés qui ont été écrits par Zora Neale Hurston, anthropologue, militante et artiste afro-américaine (États-Unis d'Amérique) des années 1930, qui a inspiré une génération de penseurs et d'écrivains noirs spécialisés dans les droits de l'homme à travers l'écrit de compilations folkloriques, d'essais autobiographiques, de fictions ethnographiques, de nouvelles, de récits et romans. Formée par Franz Boas à 1'Université de Columbia et collègue de figures clés de l'anthropologie tels que Ruth Benedict et Margaret Mead, le parcours de Hurston a été différent: bien qu'ayant été une auteure prolifique, critique et particulièrement originale, l'anthropologue est morte dans la pauvreté et dans l'oubli de ses pairs. Notre travail vise à contribuer à la revendication de la place de Hurston dans les mémoires de l'anthropologie et de la culture. Dans l'explication du processus de traduction, nous faisons fort des outils théoriques-méthodologiques de l'intersectionnalité et de la décolonialité, en questionnant la solidité du canon anthropologique à travers la traduction culturelle des voix qui ont été subordonnées dans le dialogue entre espaces Sud-Sud.

Mots-clés : Zora Hurston, traduction, extension, intersectionnalité, anthropologie. 


\section{Introdução}

A escolha, leitura e tradução do inglês para o português de textos de Zora Neale Hurston, antropóloga afro-norte-americana dos anos 1930 foi, dessa vez, o catalisador de nosso diálogo entre conhecimentos antropológicos e da cultura produzidos entre margens e espaços Sul-Sul (Sousa Santos, 2010) no intuito de nos alinharmos com outras memórias e heranças de conhecimento em chave interseccional e decolonial.

Nosso projeto se encontra situado no contexto da educação superior brasileira: entendemos relevante destacar o caráter historicamente racista e elitizado da mesma a despeito da democratização através de diversas políticas educativas implementadas entre 2003 e $2015^{2}$ (Silva e Melo, 2018). Apesar destes processos recentes, a gravitação em torno de uma educação elitizada e excludente em termos raciais nas universidades federais continua impactando na escolha de temas, metodologias e, finalmente, recursos bibliográficos dentro das áreas e especialidades de pesquisa. Nesse ponto, situamos a responsabilidade histórica de pluralizar as leituras obrigatórias e disponíveis num leque que contemple a diversidade da intelectualidade negra e feminina em diversos contextos, articulando este projeto de extensão como uma contribuição aos processos mais amplos de reparação epistêmica em curso (Carneiro, 2005). Com esse intuito, nos aproximamos de um debate sobre os clássicos que constituem o cânone antropológico, tensionando os motivos que contribuem para a manutenção e

2 Destacam-se o programa PRO-UnI, FIES, a Lei de Cotas e as políticas de interiorização das IES (Institutos de Educação Superior), como medidas para favorecer o acesso ao ensino superior de população anteriormente marginalizada (habitantes do interior, comunidades tradicionais, população negra e pobre, dentre outras) e as leis 10.639 e 11.645 no que diz respeito à inclusão de conteúdos sobre história africana e afro-brasileira e indígena na educação básica (Gomes, 2017). visibilidade de certos textos, enquanto que outros são deixados de fora. Após essas duas considerações de índole sociopolítica e teórica, nos atemos à obra da antropóloga Zora Neale Hurston a partir da tradução de textos escolhidos da autora e de uma leitura de seu itinerário biográfico, colocando a sua vida em diálogo com a riqueza da sua obra, sempre controversa e radicalmente original. $\mathrm{Na}$ apresentação dos materiais traduzidos nos interessa evidenciar o processo de tradução cultural, realizado não somente através da prática tradutória restringida à cena textual, mas também por meio de um diálogo mais amplo com aspectos da prática cultural (Bhabha, 1994) por meio de intervenções, performances e atividades de ensino-aprendizado, ensaiando formas criativas de apropriação do texto. Finalizando o artigo, nos permitimos partilhar uma breve análise do corpo textual traduzido, destacando a sua importância para o âmbito da discussão antropológica e cultural.

\section{Antropologia e justiça epistêmica: do resgate à reparação}

Meu propósito central como estudante é o de aprofundar o conhecimento geral a respeito de meu povo, fazer a ciência e as artes musicais da minha gente avançar, mas de um jeito Negro e longe do jeito do homem branco.

Zora Neale Hurston, Requerimento de Bolsa, John Simon Guggenheim Memorial Foundation, 1933 (como citada em Cotera, 2008, p. 71)

Uma institucionalidade colonizadora ultrapassa a antropologia brasileira, colocando-a no lugar de ciência ao resgate de conteúdos culturais diversos que depois serão cristalizados em museus, textos acadêmicos e belos produtos audiovisuais que alimentam uma imagem falaciosa e folclorizada do Brasil como paraíso da democracia racial. De acordo com José Jorge de Carvalho (2018), ainda que tenha se iniciado o processo de reparação histórica de 
comunidades negras e indígenas a partir das cotas étnico-raciais na educação superior brasileira, há uma longa estrada a ser percorrida. Pois, apesar das cotas terem enegrecido em alguma medida as salas de aula, esse enegrecimento continuará sendo relativo enquanto não sejam acolhidos e ensinados os conhecimentos, olhares e epistemes sensíveis de ditas comunidades.

Um veículo privilegiado para a incorporação de outros saberes ao campo universitário seriam certamente os e as professoras negres ${ }^{3} \mathrm{ou}$ pertencentes a outros coletivos marginalizades. Porém, os corpos docentes das universidades públicas federais brasileiras são predominantemente compostos por pessoas brancas. Conforme os dados do Censo da Educação Superior de 2018, professores negres são apenas $30 \%$ dos docentes universitários, e 14\% dos acadêmicos que desenvolvem pesquisas (Instituto Nacional de Estudos e Pesquisas, 2018). Apenas cinco universidades públicas em todo o Brasil tem maioria de professores negres. Podemos perceber que com todos os avanços, "o movimento negro educador" (Gomes, 2017) tem pela frente uma enorme luta pela justiça epistêmica.

3 Usamos o morfema "e" para nos referirmos ao feminino, ao não-binário e ao masculino como alternativa escolhida dentro da proposta mais ampla da linguagem inclusiva. Nossa escrita procura fortalecer a tendência de instituições do Estado, organismos internacionais como a ONU e dezenas de universidades e grupos parlamentares latino-americanos e espanhóis que, a partir da pressão de movimentos de mulheres e feministas, se posicionaram explicitamente em prol da prática de uma linguagem inclusiva em termos de gênero (Wasserman \& Weseley, 2009; Quintero, 2019). Vale dizer que, não somente o espanhol e o português estão vivenciando esses processos, mas também línguas como o finlandês, o sueco e o inglês. No caso do inglês, o pronome pessoal them passou a ser utilizado para se referir a pessoas com gênero neutro, e foi uma das palavras mais procuradas no google durante 2019 (Merriam Webster News, 2020).
A Carta dos Direitos Humanos das Nações Unidas (ONU, 2009 [1948]), reconheceu, dentre outros direitos, o direito a ter um nome. Os povos indígenas latino-americanos e de outras latitudes do mundo demandam modificações que coletivizam essa proposta: o direito a existir coletivamente enquanto povo (ou grupo étnico), do qual se desprende o direito à auto-adscrição étnica (Rivera Cusicanqui, 2010; Sousa Santos, 2010). O direito de expressar o que se é sem intermediários interpretativos atinge não somente os aspectos sociais e culturais das nações, mas também aqueles que são propriamente epistêmicos (Carneiro, 2005). Esse direito se associa com o termo "lugar de fala" proposto pela filósofa brasileira Djamila Ribeiro (2019), que se propõe a discutir a necessidade de incluirmos na nossa formação, debates e bibliografias - isto é, no nosso horizonte de referenciamentos acadêmicos - autorias que sejam representativas de segmentos historicamente marginalizados na sociedade.

Entre as iniciativas contra-hegemônicas que nos inspiram se encontram o projeto Encontro de Saberes (Carvalho, 2018), ${ }^{4}$ a experiência universitária da UNILAB, ${ }^{5}$ as traduções do

4 Existem mais de oito universidades brasileiras nos níveis da graduação e da pós-graduação, e neles são chamades mestras e mestres das culturas populares para darem aulas como professores dentro de cursos diversos, tais como arquitetura, psicologia, artes cênicas e antropologia. Ali, os lugares de fala são potencializados de forma direta dentro dos espaços acadêmicos, com as presenças de lideranças de comunidades - quilombolas, indígenas, do Movimento Sem Terra, de terreiro, ribeirinhas, ciganas — no papel de educadores/as.

5 A UNILAB é um projeto em curso de universidades federais interiorizadas (Ceará e Bahia) e internacionalizadas através de acordos de cooperação Sul-Sul com os países de língua oficial portuguesa (PALOPs): Cabo Verde, Guiné Bissau, São Tomé e Príncipe, Moçambique, Angola e Timor Leste. O currículo da unILAB incorpora temáticas, leituras e metodologias africanas, afrodescendentes e afrocentradas nos conteúdos obrigatórios, assim como também recebe ingressos semestrais de alunos 
grupo de pesquisa FEMPOS/UNILAB do Campus São Francisco do Conde na Bahia ${ }^{6}$ e o blog "Filosofia Africana", do professor de filosofia da Universidade de Brasília Wanderson Flor do Nascimento. ${ }^{7}$ Nesses espaços, através de práticas de reparação epistêmica se questiona o espaço de prestígio que é a universidade pública federal brasileira com saberes e formas de conhecer que questionam o logocentrismo e o autoritarismo acadêmico, na compreensão de que toda ação pela teoria deve ser uma prática libertadora (hooks, 2019).

\section{Aspectos teórico-metodológicos}

Não, eu não choro para o mundo: estou ocupada demais afiando minha faca de ostras.

Como Eu me Sinto Sendo uma Pessoa de Cor. World Tomorrow, Zora Neale Hurston (1995 [1928])

Nosso trabalho de tradução da obra de Zora Neale Hurston pretende contribuir para reivindicar o seu lugar dentro das memórias da antropologia e da memória cultural. No pro-

internacionais dos países antes mencionados, junto com os ingressos padrão de discentes via o Sistema de Seleção Unificada (SISU) do Governo Federal.

6 Seguindo a preocupação relativa à necessidade de socializar material de autoras/es não traduzidos ao português emerge recentemente o projeto de tradução de bibliografia feminista decolonial e queer africana do grupo de pesquisa FEMPOS/UNILAB, liderado pela professora da UNILAB , Bahia, Caterina Rea, e que tem como um dos seus resultados, a publicação Traduz̨indo a África Queer pela editorial Devires (2018), disponível online. Esse material reúne textos acadêmicos e ativistas fundamentais de autores/as queer, sendo uma publicação de caráter único em língua portuguesa.

7 Enfatizando a tradução como mecanismo de democratizar o acesso à produção intelectual africana, o blog "Filosofia Africana", coordenado pelo professor de filosofia da UnB Wanderson Nascimento se dedica à tradução para o português de textos magistrais do pensamento africano e diaspórico contemporâneo, com traduções de qualidade acadêmica. https:/ / filosofia-africana.weebly.com/, recuperado em 18 de abril, 2020. cesso tradutório, nos valemos das ferramentas teórico-metodológicas da tradução cultural em consonância com um olhar interseccional e decolonial. O conceito de tradução cultural decorre, em grande parte, da leitura de Homi Bhabha (1994), um conceito usado para denotar o processo de transformação, linguística ou não, em uma dada cultura. Nessa concepção, a tradução linguística é usada como uma ferramenta ou metáfora na análise da natureza da transformação e do intercâmbio nas culturas.

Dessa maneira, a ideia de tradução cultural contempla a tradução como uma atividade mais ampla da comunicação entre grupos, e como tal, está mediada por relações de poder. Nos trânsitos entre fronteiras que a tradução possibilita é possível reconhecer diálogos entre culturas, grupos e identidades em contínua transformação: a apropriação dos originais se configura como um ato de resistência (Benjamin, 1999[1923]) e gera ecos criativos, com ressonância local. Nossa metodologia é nutrida pelo posicionamento de intelectuais e ativistas que questionam a colonialidade do saber (Mendoza, 2019), tais como Homi Bhabha (1994), Asad (1996); Gayatri Spivak (2010), entre outres. Nessas linhas, é uma metodologia que cultiva uma natureza crítica, reflexiva, híbrida, dialógica e experimental, colocando seu foco não somente no produto - que, nesse caso, refere a peças escolhidas da obra de Zora Hurston - mas também nos processos epistemológicos, políticos, culturais, sensoriais e cognitivos que fizeram essas peças possíveis. Ecoando nas propostas da descrição densa estabelecida pelo paradigma da antropologia interpretativa (Clifford \& Marcus, 1986), o linguista ganês Kwame Anthony Appiah (2000) definiu como "tradução densa" [thick translation] o exercício simultâneo de tradução e reflexão sobre o processo de tradução com atenção aos contextos. 
Nesse sentido, há uma série de hábitos acadêmicos que enfrentamos cotidianamente e que estão fortemente ligados à repetição de um cânone eurocentrado que está imbuído nos nossos conteúdos curriculares (Carvalho, 2018). As bibliografias dos programas disciplinares com as quais nos deparamos bem podem representar o topo do iceberg de uma realidade pétrea: o cânone das nossas ciências, construído como uma Grande Narrativa da história e da teoria de cada disciplina, é uma verdade invisível, dificilmente enunciável. Para Harold Bloom (1991) o cânone se constitui a partir de modelos de excelência literária baseados maioritariamente em critérios estéticos que representam determinados momentos históricos e culturais. $\mathrm{O}$ autor, de origem norte-americana, advoga pela "autonomia estética do cânone", em uma perspectiva que manifesta a procura por uma normatividade intrínseca às obras e uma desconfiança das lutas identitárias, que eram chamadas por ele, off the record, de "narrativas do ressentimento" "Vozes dissonantes se alçaram contra essa perspectiva, salientando aspectos centrais de uma discussão teórico-metodológica relativa não somente à importância do cânone, mas também aos tensionamentos que existem fora dele e que, de alguma forma, o constituem.

Jaime Ginzburg (2004) questionou frontalmente a postura deste autor, salientando a historicidade do cânone e os problemas inerentes aos procedimentos de construção de saberes disciplinares que "confiam mais nos mortos do que nos vivos" (Bloom, 1991 como citado em Pinheiro, 2019, p. 9). Nesse sentido, os mecanismos que sacralizam determinados textos são sinalizados como os principais reprodutores das violências epistêmicas. Ainda sobre o peso

8 "Defesa do cânone e fúria contra critério identitário marcaram Harold Bloom". Notícia no Jornal Folha de São Paulo, 26-10-2019. funerário que encharca esses critérios de autoridade, o jovem filósofo chinês Eugene Sun Park: "o cânone filosófico consiste, quase que exclusivamente, em [um conjunto de leituras sobre] homens brancos e mortos".

A professora de literatura de origem indiana Ankhi Mukherjee complementa essa visão propondo que as peças consideradas "clássicas" são uma espécie de "aristocracia de textos" legitimados com um poder que torna esse status canônico, conseguindo "congelar a arte literária da memória" (Mukherjee, 2010, p. 1029) através de mecanismos de poder dentro dos diferentes campos disciplinares. A canonização de determinades autores e temáticas em detrimento de outres pode ser compreendida como um processo histórico de permanente recriação de mitos de origem disciplinares (Connell, 2012) ativados como dispositivos discursivos que são posteriores às origens mesmas das disciplinas cuja gênese pretendem narrar. Conforme a proposta da cientista social australiana Raewyn Connell (2019), os textos e autores clássicos são fruto de uma invenção atemporalizante dentro de seu próprio tempo, comunidades imaginadas no sentido historiográfico (Pinheiro, 2019). Esse paradoxo não costuma ser colocado em questão pelas disciplinas, até o ponto que os textos canônicos passam a ser consideradas a "língua franca" através da qual as disciplinas realizam suas trocas comunicativas.

A professora brasileira Vanessa Riambau Pinheiro (2019) analisa, com foco no seu trabalho em Moçambique, como o cânone é construído de formas específicas dentro das narrativas nacionais e disciplinares. Por meio da análise da literatura moçambicana, ela demonstra as maneiras em que o cânone, apresentado como

9 Post em Blog. Why I Left Academia: Philosophy's Homogeneity Needs Rethinking. http://read.hipporeads. com/why-i-left-academia-philosophys-homogeneity-needs-rethinking/ recuperado em 04 fevereiro, 2020. 
um lugar de recursos rígidos e fixos na atemporalidade, é, na verdade, uma arena submetida a tensões, disputas e conflitos permanentes na procura da territorialização da legitimidade das obras. Se aproveitarmos o caso moçambicano para pensar na situação brasileira a partir das ferramentas heurísticas providas pelo diálogo entre espaços Sul-Sul (Mohanty, 1984; Sousa Santos, 2010), podemos observar que as ciências sociais brasileiras têm sistematicamente produzido a ausência de epistemologias negras, quilombolas, indígenas, vindas de espiritualidades afrocentradas, camponesas, caboclas, com deficiência, assim como de pessoas trans e travestis e dissidências sexuais - até o ponto em que algumas acadêmicas ativistas têm proposto a "epistemologia do barraco" como forma radical de manifestar visibilidade (Assunção da Silva e Fernandes de Souza, 2017).

O semiólogo argentino Walter Mignolo (1991) aponta para a importância da recepção de leitores não especializades no processo descolonizador de fortalecimento dos textos em vias de legitimação: "devemos convidar estudantes a discutir criticamente as estratégias de formação e transformação do cânone" (p. 14), questionando simultâneamente a universalidade, por uma parte, e o caráter regional, por outra parte, com que são etiquetadas diferentes produções dentro da literatura. Se nenhuma produção literária é intrinsecamente "universal" ou "regional", quais são os dispositivos pelos quais umas e outras são instituídas como tais? As estratégias de ensino do cânone devem permitir uma relação permanente e crítica com ele, ciente da sua tendência à perpetuação de hegemonias (Laist, 2009) e interessada em ativar as ferramentas teórico-metodológicas necessárias para questionar as próprias bases desse statu quo. Nesse sentido, acreditamos que a discussão sobre o cânone e seus tensionamentos deve ter uma imediata contraparte com a discussão política das interseccionalidades, a justiça epistêmica e as conquistas do movimento negro (Gomes, 2017).

Nosso aproveitamento da análise interseccional - que é uma perspectiva teórica com foco fortemente sócio-antropológico ${ }^{10}-$ aos estudos da tradução propõe a articulação simultânea de duas dimensões: a produção autoral e a legitimação dos textos. A interseccionalidade nos permite indagar os motivos aparentemente externos às obras mas que se mostram, de fato, intrínsecos à existência das mesmas nos territórios discursivos reconhecidos como canônicos. ${ }^{11}$ Finalmente, a mesma análise interseccional nos provê de elementos que fazem tangível a direção na qual devem ser ativadas práticas de justiça epistêmica que atinjam nossas bibliografias, traduções, pesquisas, política de cotas, concursos públicos e outras formas de reparação histórica.

10 A perspectiva interseccional nas ciências sociais surge a partir de demandas de direitos específicos nos Estados Unidos nos anos 1970 (Crenshaw, 1991; Hill Collins, 2015) , e se difunde pelo Brasil a partir do trabalho de acadêmicas e militantes que são, majoritariamente, feministas e negras (Carneiro, 2011; Gonzales, 1980; Ribeiro, 2019; Akotirene, 2018), atentando à necessidade de pensar nos sistemas racista, classista e machista, assim como em outros eixos de opressão historicamente definidos segundo as diversas geografias, de forma integrada.

11 Branco et al. (2018) demonstraram a partir da análise interseccional de programas disciplinares de Teoria Antropológica de quatro universidades da América do Sul que a maioria dos textos propostos eram de autores homens, brancos de origem europeia. Cisgeneridade, classe, deficiência e orientação sexual não foram trabalhados neste estudo, mas é necessário colocar que são fatores que fazem parte de uma análise interseccional consistente. No texto, as autoras se debruçam sobre os dispositivos de saber-poder que fazem com que esse conhecimento, muito específico e que refere a um grupo numericamente minoritário que é geográfica, racial e corporalmente situado, é considerado universal. 
Para a crítica indiana Gayatri Spivak (2000), é necessário que exista uma modificação radical nas condições da escuta para que textos marginalizados pelas forças centrífugas do cânone venham a se tornar audíveis e inteligíveis para as audiências especializadas. $\mathrm{O}$ trabalho de tradução que ela propõe no texto "Pode o Subalterno Falar?" não reduz sua busca à preciosidade linguística, mas constrói seu foco no esforço sistemático pela reconstrução histórica de um contexto no qual o discurso da sujeita subalterna passa a ser inteligível e, simultâneamente, legítimo.

Ao revisitarmos a teoria e a história da antropologia (Eriksen \& Nielsen, 2001) a partir da compreensão crítica dos processos de legitimação do conhecimento (Echazú Böschemeier et al 2017; Echazú Böschemeier, 2019), observamos que a disciplina tem cultivado uma obediência quase cega aos chamados "pais fundadores" da disciplina. Estudamos suas teorias em sala de aula, incorporamos suas polêmicas de corredor e tomamos "notas marginais de seus 'agradecimentos' a esposas e namoradas sem as quais esse trabalho nunca teria sido possível na quase totalidade das suas obras" (Branco et al., 2018 , p. 72). Na perspectiva spivakiana, a obra de Zora Neale Hurston adere às características de um discurso subalternizado: tido, por definição como ininteligível, não acadêmico, militante, poético-literário, ficcional, excessivamente autocentrado. Propomos o estudo e difusão de sua vida e obra como forma de restituição dos parâmetros que permitem enxergar o valor da sua produção intelectual e suas contribuições epistemológicas, teóricas e metodológicas à antropologia.

Concebemos a pesquisa, tradução, aprendizado e difusão do pensamento de Zora Neale Hurston não como um resgate, mas como uma ação de fortalecimento de processos de reparação epistêmica, dentro da qual a troca linguístico-cultural que é a tradução se configura como uma chave de desbloqueio do acesso aos seus textos. Na próxima seção, dedicaremonos a apresentar nossa autora a partir de uma aproximação biográfica e interseccional.

Destarte, podemos inferir que o resgate epistêmico é um processo situado na história e construído perante diálogos, várias metodologias, e contradições, sendo essas, historicamente, os motores que permitem compreender a obsolescência do cânone literário. Para somar à abordagem teórico metodológica, em um caráter já conclusivo, coloca-se em todo o processo a possibilidade da reflexão acerca da conformação do cânone, suas influências e contraposições. Sabendo-se que o cânone ocidental faz parte de um sistema fechado de conteúdo, discurso e referências, e que representa aos seus correligionários históricos uma concepção silogística de valores estéticos universais e universalizantes, assim como o imperativo categórico da filosofia kantiana. Por consequência há a recorrente ideia de "obra-prima", que permeia os sete continentes, operando como um padrão de medidas para a construção de discursos posteriores, tal qual a descrição de cânone como kanon, do grego, vara de medir (Reis, 1992).

Posteriormente, há o convite a refletir que na compreensão de cânone há uma implícita hierarquização constituída de uma série de pressupostos dentro da educação, como a manutenção dos binarismos educador e educado, civilização e primitividade, belo e feio, e assim por diante. Quando são investigadas as características refletidas nas epistemologias que constituem o cânone literário atual, deparamo-nos com um contexto de colonialismo e moral judaico-cristã, motores históricos do epistemicídio dos saberes das comunidades locais. A literatura e a ciência emergem, assim, como categorias universais de produtos ahistóricos, tornando o que há fora do cânone um mero sopro de vozes ininteligíveis, inalcançáveis e inaudíveis. 
Sabe-se que ao falarmos da relação autor e obra, compreendemos a relação de sujeitos e objetos presentes no mundo, num contexto, e numa história. Dessa razão pode-se partir para a reflexão foucaultiana da chamada "função-autor", e sobre a impossibilidade de tratar o autor de uma obra como um mero sujeito metafísico de caráter descritivo, pela razão de que o autor esculpe o texto que escreve, caracterizando-lhes. Trata-se de uma das estruturas do paradigma da episteme, da própria questão do cânone literário. O termo "hierarquização" ali supracitado, na reflexão de Foucault remete explicitamente ao poder.

A função-autor está ligada ao sistema jurídico e institucional que contém, determina, articula o universo dos discursos; ela nasce se exerce uniformemente e da mesma maneira sobre todos os discursos, em todas as épocas e em todas as formas de civilização; ela não é definida pela atribuição espontânea de um discurso ao seu produtor, mas por uma série de operações específicas e complexas. (Foucault, 2006, p. 57)

Dessa forma, a estrutura metodológica aqui contida é um convite à identificar o caráter social dos conceitos e compreender suas determinações históricas. É convidativo também o estudo contínuo sobre o entendimento de "clássico", questionado como a mera produção de uma obra de peso que serve como fonte de inspiração para discursos posteriores, e colocando sob o foco seu lugar como referência paradigmática a epistemologias eurocêntricas. Como definir, então, o caráter dos discursos que surgiram após os clássicos ou em decorrência de sua inspiração? E o que dizer daqueles que tensionaram seus pressupostos básicos? Eles poderiam, algum dia, se tornarem clássicos? Sendo assim, eles teriam ainda as características do colonialismo ou seriam capazes de encarnar a ramificação de novas e revolucionárias epistemologias? São essas algumas das dúvidas metódicas que devem acompanhar os e as leitores/as daqui para frente, em um caminho de questionamentos permanentes.

\section{Zora Neale Hurston: uma aproximação biográfica e interseccional}

Eu sou o eterno feminino com seu colar de contas"

Zora Neale Hurston, Como Eu Me Sinto Sendo uma Pessoa de Cor (1928).

Zora Neale Hurston não poderia ser colocada como uma personalidade "excepcional", pois a contribuição dela se situou junto com a de diversas intelectuais negras que agiram no mundo ativista, artístico e poético da época. ${ }^{12}$ Pelo contrário, todo autor(a), toda figura representativa de determinada rama da ciência requer de um marco social no qual a sua prática adquira sentido: os acontecimentos biográficos podem ser definidos "como colocações

12 Neste sentido, podemos citar algumas mulheres centrais do movimento artístico-político do Harlem Renaissance como a escritora Regina M. Anderson (1901-1993), a cantora e dançarina Josephine Baker (1906-1975) e a poetisa Georgia D. Johnson (18801966). Na época, a cena política negra contava com organizações muito relevantes. Uma delas, a UNIA-United Negro Improvement Association, contou com engajamento feminino significativo, entre quem destaca-se a editora do seu jornal The Negro World, Amy Jacques Garvey; este jornal chegou a distribuir 60.000 exemplares em diversos países, com notas em inglês, francês e espanhol. Esta organização promoveu o desenvolvimento e avanço autônomo das comunidades negras e a volta à África (Domingues, 2017, p. 131). Outra organização relevante no debate sobre a questão racial, era a National Association for the Advancement of Colored People (NAACP), que tinha seu antecedente no Niagara Movement, e que advogou contras as leis segregacionistas, contra os linchamentos e em prol da integração racial. Entre outras mulheres relevantes da organização podemos mencionar a sufragista Mary White Ovigton e a afro-norte-americana Ida Wells, jornalista e educadora (Sítio oficial da organização: www.naacp.org, recuperado em 26 de março 2020). 
e deslocamentos no espaço social" (Bourdieu, 1986, p. 71).

Nascida em 7 de janeiro de 1891, no Alabama, Zora Neale Hurston mudou-se para Eatonville, na Flórida, em 1894, fazendo desta cidade o palco posterior para seus textos literários e campo de pesquisa antropológica. Conforme o artigo de Alice Walker (1975), "Procurando Zora Neale Hurston" (nossa tradução), Eatonville era um município rural do sul, no qual todes seus habitantes eram negres incluindo as autoridades, prefeito, professores, polícia. Assim, dentro de um Estados Unidos constituído na base da segregação racial, a autora vivencia parte da sua infância e adolescência em "uma comunidade integralmente negra, onde predominava a lealdade e a unidade. Onde orgulho negro não era uma novidade" (Walker, 1975, p. 3). Essa experiência de vida, se conecta fortemente com algumas das suas declarações mais controversas como ser contra a integração racial nas escolas.

Filha de um pastor protestante e uma professora, Zora interessou-se por literatura e por ouvir as histórias que os adultos contavam. Em 1916, começou a trabalhar como empregada após ser expulsa do colégio interno que frequentava por falta de pagamento da mensalidade. Em 1917 retorna ao estudos, entrando no Morgan College, escola de ensino médio da tradicional instituição Morgan State University. Em 1918, Zora começou seus estudos na Howard University (Washington, D. C.), se formando em Letras em 1920, tendo estudado com nomes como Lorenzo Dow Turner (1890-1972), linguista afro-americano pioneiro nos estudos da linguagem, e Dwight O. W. Holmes (18771963), sociólogo e ativista dos direitos civis afro-norte-americanos.

Ainda em Howard University, Zora é encorajada por Charles S. Johnson, editor do jornal Opportunity, para iniciar seriamente sua carreira como escritora. Em decorrência disto, ela se inscreveu para o concurso literário do jornal de Johnson, submetendo dois contos e uma peça, ganhando o segundo lugar em ambas as categorias. O mais importante, talvez, não tenha sido a premiação recebida, mas a atenção que chamou das elites intelectuais da época, recebendo, a partir disso, uma bolsa de estudos no Barnard College. O Barnard College se colocava à época como uma faculdade privada de artes liberais para mulheres muito particular: ela surgiu em resposta à falta de mulheres na Columbia University que pouco depois veio a ser incorporada a essa instituição maior.

Já em Barnard College, Zora mudou seu foco de estudo ao matricular-se em um curso eletivo de Antropologia, onde se destacou ao escrever um artigo para a disciplina. Foi por meio desse artigo que Hurston conheceu Franz Boas, que seria seu mentor durante os anos nos quais pesquisou sobre Antropologia e a incentivou a "abandonar a literatura pela ciência" (Cotera, 2008, p. 78) (nossa tradução). Zora, contudo, continuou transitando nos dois caminhos. Durante o dia moldava seu corpo ao espartilho da pesquisa científica e lutava contra o racismo científico que rondava a época, e, durante a noite, colaborava com outros intelectuais como Langston Hughes, Wallace Thurman e Gwendolyn Bennett na produção de Fire!!, jornal de edição única que dedicavase aos jovens artistas afro-americanos.

A primeira experiência significativa de trabalho de campo de Hurston não obteve bons resultados. Após a conclusão do curso em Barnard, Zora embarcou em uma viagem a Eatonville, a fim de procurar gravar e estudar os costumes, histórias, danças e outras práticas populares próprias da cidade onde ela cresceu. Ao chegar ao local, porém, Hurston não encontrou nenhum tipo de receptividade por partes dos moradores que tinham sido 
seus vizinhos, o que acarretou em um frustrante amontoado mínimo de material obtido. Mais tarde, ela escreve que não foi a falta de talento para pesquisa que a impediu de obter resultados relevantes, mas sim sua abordagem errônea (Cotera, 2008). Em retrospectiva, nós nos perguntamos se a abordagem era mesmo "errônea" ou eram errados ou inadequados os parâmetros a partir dos quais era lida a cientificidade dos materiais produzidos por Hurston. Por outro lado, a ideia de alteridade como constitutiva da produção de conhecimento antropológico, operava de uma forma muito particular e inovadora para a época em um trabalho de pesquisa voltado para o entorno familiar da infância da autora. De que forma aquela proximidade e distância poderiam ser traduzidas nos termos da relação etnográfica entre o eu e o Outro? Todas essas considerações metodológicas seriam abordadas de forma muito posterior à produção da autora (Clifford \& Marcus, 1986), colocando Zora Hurston como uma pioneira do fazer antropológico do século XXI.

O "fracasso" da jovem antropóloga na expedição e os nulos resultados obtidos se potencializou com uma insatisfação crescente de Franz Boas acerca dos métodos adotados por Hurston na condução dessas primeiras pesquisas. De fato, enquanto Boas estava interessado no desenvolvimento de metodologias a exercitar o pré-requisito intelectual do estranhamento etnográfico (Cotera, 2008), Zora procurava nas próprias raízes as histórias e músicas do folclore negro com uma perspectiva de registro localizado dos detalhes da cultura viva de seu povo - uma perspectiva emergente do próprio ponto de vista [standpoint perspective]. É preciso dizer que uma perspectiva particularista reunia ambos os olhares do mestre e da aluna: descrição contextualizada historicamente, foco nos detalhes sem perder de vista as mudanças da história e a diversidade de vozes presentes no trabalho etnográfico.

É assim que, se os dois se interessavam pelo registro cuidadoso de traços culturais, Hurston não fazia jus aos protocolos de estranhamento etnográfico e posterior interesse pelo estranho como abordagens científicas enaltecidas por Boas para a pesquisa etnográfica. No caso de seus estudos etnográficos realizados no Sul dos Estados Unidos, seu olhar sobre o material registrado não era somente o de preservar do esquecimento traços específicos de uma comunidade cuja cultura estava ameaçada de extinção: ocupando o lugar nativo que lhe correspondia, ela trazia as outras vozes da comunidade para um encontro que registrava criativamente essa situação polifónica. $\mathrm{O}$ mandato fragilizante da extinção da cultura era deslocado por uma perspectiva que mostrava o humor, a resistência, a resiliência e a reinvenção permanente das pessoas dentro de seus entornos culturais.

Ao retornar do campo, Zora consumou o que podemos ver hoje como uma forma de "suicídio acadêmico". Em uma prática cuja motivação mais nítida ainda nos é desconhecida, ela submeteu um resumo insuficiente e confuso contendo os resultados da viagem de expedição à Flórida e publicou, no Journal of $\mathrm{Ne}$ gro History, um artigo (Cotera, 2008) baseado numa entrevista com um idoso sobrevivente do último navio de escravos levado para os Estados Unidos, que mais tarde foi taxado como plágio. Acerca do porquê Zora encerrou sua carreira oficial na pesquisa acadêmica, destacamos aqui duas especulações que não são excludentes: o abandono da sua carreira acadêmica devido às exigências permanentes, por parte de Boas e Woodson (os dois homens que dirigiram sua expedição à Flórida), para adequar a sua pesquisa e escrita acadêmicas aos parâmetros da época e, por outra parte, um distanciamento 
consciente que provava, talvez, a sua própria necessidade de reavaliar as metodologias de pesquisa que ela havia aprendido dentro dos estudos acadêmicos canônicos, confrontando seus pressupostos "como uma etnógrafa nativa de cabeça erguida" (Cotera, 2008, p. 17, nossa tradução). Podemos aventurar uma terceira hipótese, considerada parcialmente por Cotera: a possibilidade de que sua agenda de pesquisa e sua urgência de publicação estiveram em aberta discordância com os requerimentos impostos por esse mundo acadêmico que ela permanentemente questionava nos seus escritos, nas suas performances e nas suas práticas políticas.

É preciso salientar que a vida e obra de Zora N. Hurston possui algumas peculiaridades que fazem da tradução da sua obra uma tarefa especialmente significativa. Em primeiro lugar, ela foi uma mulher negra que obteve parte da sua formação na Universidade de Columbia sob a orientação de Franz Boas, estudioso que é considerado até hoje um dos "pais" da antropologia moderna. Essa estreita relação de Zora com um dos centros intelectuais mais importantes da antropologia no mundo, na época e até hoje, já a coloca em um lugar especialmente instigante.

Nas observações da escritora, poetisa e ativista afro-norte-americana Alice Walker, Zora Neale Hurston é "uma das autoras não lidas mais significantes" (Walker, 1975, p. 1, nossa tradução). De fato, seria esperável a encontrarmos dentro do cânone da antropologia clássica junto como suas colegas e contemporâneas Ruth Benedict e Margaret Mead.

Uma particularidade da contribuição dessa autora se encontra nas facetas ativistas e artístico-performáticas que desenvolveu: navegando por estilos fortemente autobiográficos e se apoiando na potencialidade de seu próprio acesso privilegiado a materiais vindos de vozes extremamente marginalizadas, ela desafiou os estreitos limites da antropologia de entreguerras com uma proposta radical e pouco preocupada com honrar as "linhagens de mestres fundadores" próprias das linhas hegemônicas da próprias das antropologias centrais (Eriksen e Nielsen, 2001). A antropologia dos anos 1930 se debatia entre a consolidação da escola estrutural-funcionalista na Inglaterra, o trabalho des alunes de Marcel Mauss que tinha sido interrompido na primeira guerra mundial e a emergência de uma sistematização antropológica em uma dimensão nunca antes vista a partir da proposta da escola culturalista norte-americana (Eriksen e Nielsen, 2001).

Se lançando na direção contrária ao progressismo liberal implícito na abordagem culturalista norte-americana (mais preocupada com a diversidade do que com a desigualdade social e sustentada por epistemologias de tom fortemente empirista), Zora N. Hurston se colocou como relatora de uma realidade social que a atravessava e à qual não conseguia apreender como um mero objeto de uma ciência social higienizante pois essas realidades faziam parte dela. É muito interessante observar as maneiras pelas quais Hurston questionou uma série de pressupostos da ciência antropológica que posteriormente foram abraçados pela pós-modernidade, pela pós-colonialidade e pela decolonialidade.

É de praxe considerar a existência da perspectiva pós-moderna na antropologia a partir dos anos 1970 em diante. Segundo mitos fundacionais deste movimento de ideias que circulam nos livros de textos didáticos para 0 aprendizado da história da disciplina (Eriksen e Nielsen, 2001), a pós-modernidade na antropologia teria sido impulsada pela publicação póstuma do diário íntimo de Bronislaw Malinowski (Malinowski, 1989 [1967]). 
Tal movimento observa depois seu nascimento oficial com a chamada "virada literária" [literary turn] na antropologia (Clifford \& Marcus, 1986). Ali, se postulou o fazer antropológico como uma forma de crítica cultural, se colocaram as produções etnográficas como formando parte de um gênero literário per se e se relativizaram as contribuições de uma ciência antropológica clássica fundada no empirismo. A partir da leitura discursiva dos textos etnográficos, foram analisadas as estratégias de verossimilhança (Geertz, 2005 [1988]), compreendidas como dispositivos de construção factual de verdades parciais.

$\mathrm{Na}$ análise da obra de Hurston que antecipamos aqui é possível observar vários elementos que colocam seu trabalho não somente como pós-moderno, mas também como pós-estruturalista e decolonial em vários sentidos: antropologia como crítica cultural, apagamento das fronteiras entre gêneros textuais, conhecimento corporificado, descentramento a respeito do logocentrismo, questionamento radical da dicotomia sujeito-objeto, reconhecimento da provisoriedade das produções científicas, visibilização de epistemologias situadas em pontos de vista [standpoint epistemologies], diálogo aberto entre ciência e produção cultural, assim como o que hoje chamamos lugar de fala, uma vez que ela era, além da pesquisadora, uma integrante da comunidade pesquisada. É nesse último ponto que nos apoiamos para apresentar o surgimento da obra de Zora no berço de um movimento cultural que sacudiu a história norte-americana com sua potência questionadora: o Renascimento do Harlem.

O Renascimento do Harlem [Harlem Renaissance] foi provavelmente o movimento literário e cultural afro-norte-americano mais influente da história. O início desse movimento, em 1918, trouxe várias mudanças significativas para a vida da população negra naquele contexto, as quais puderam se perpetuar e influenciar o pensamento crítico acerca dos estereótipos até os dias atuais. Os participantes do movimento buscavam estabelecer um novo conceito para "o Negro" que não estivesse associado à perspectiva dos estereótipos postos por brancos. Assim, não só mudariam a percepção de todes, mas também a relação "do negro com ele mesmo", com suas raízes e com sua identidade. $\mathrm{O}$ movimento era principalmente motivado por intensos debates que viriam a influenciar a literatura negra e a consciência sobre a questão mundo afora. Dessa forma, o movimento não ficou restrito ao distrito de Harlem, em Nova York, mas tem essa cidade como símbolo para esse acordar cultural.

Inserida nesse contexto e sendo abraçada depois como um dos grandes nomes desse movimento, Zora N. Hurston contribui significativamente tanto para a Antropologia quanto para a literatura. Sua trajetória de vida e suas contribuições para esses campos do conhecimento apresentavam singularidades no que diz respeito à maneira de ver o mundo e de reconhecer seu lugar nele.

No âmbito do Harlem Renaissance, ${ }^{13}$ desenvolveu-se o conceito "blackness", que propriamente refere-se ao desenvolvimento e valorização da negritude, da "essência" da cultura negra e a exaltação de suas variadas unidades expressivas que, naquele contexto histórico, desenvolveram um aspecto totalizante. Entende-se, dessa forma, que um dos sustentáculos do Harlem

13 Harlem Renaissance em tradução literal significa Renascimento do Harlem, em referência ao movimento cultural negro que ocorreu no bairro do Harlem em Manhattan, em Nova York nos Estados Unidos da América. Propositalmente, seus iniciadores adotaram a designação de renascença para indicar, por analogia à cultura europeia, a continuidade de uma cultura negra anterior à experiência da colonialidade que agora retornava. 
Renaissance foi além da estruturação da cultura como um monumento de influência, denúncia e requisições, a criação e nutrição de uma intelectualidade negra politizada e engajada.

O movimento cultural mencionado deu-se num contexto histórico de uma marcante política de segregação racial e negação da identidade afro-americana. A movimentação desta mobilização cultural pertenceu aos meios urbanos de Nova York, atuando assim na reivindicação de pautas e na denúncia da capilaridade da violência colonial em suas diversas perversidades: educacional, policial, a leniência estatal, e a atuação de um grupo ultra-racista de ideário eugênico, a Ku Klux Klan, que perdura com seguidores até os dias de hoje.

Vale-se, por inferência, compreender diretamente que a proposta do Renascimento do Harlem foi a autodeterminação da expressão negra, da afirmação intelectual do negro perante a literatura, a música, as artes plásticas, a estética e a própria academia. Recuperando o vasto acervo musical e cultural do povo afro-norte-americano (processo do qual Hurston faria também parte), estimulando a fusão de novos ritmos: o mundo conheceu indiretamente o Renascimento do Harlem por algumas figuras marcantes da música, se tornando uma arte de veiculação rápida, extremamente popular e que contou com a contribuição de artistas como Louis Armstrong e Billie Holiday, por exemplo.

Os atores sociais que, em interação, construíram o Renascimento do Harlem, atuaram em diversos campos da produção de conhecimento, uns tornando-se mais famosos que outros. A perspectiva que propomos é que uma análise restrita à estética do campo artístico não nos forneceria uma resposta a respeito do porquê possam ser tão conhecidas as interpretações no saxofone de Louis Armstrong enquanto que a produção científica de Zora Hurston tenha permanecido nas margens. Nesse sentido, o campo científico aparece como muito menos permeável do que o campo das artes ao movimento de autoafirmação e autodeterminação do povo negro.

\section{Traduzindo Zora Neale Hurston}

O ciclo formal do projeto RECânone decorreu durante o segundo semestre de 2019 (2019.2), e será retomado a partir do mês de março do ano de 2020. A iniciativa é integrada por discentes da graduação e por docentes que fazem parte das áreas de Antropologia, de Literatura e de Tradução; as duas últimas vinculadas ao curso de Letras-Inglês e Letras-Português da UFRN. Contamos também com colaborações de docentes da Unilab nas áreas de História e Teoria Antropológica.

Com a junção dessas diversas áreas de conhecimento, partimos para a escolha dos textos (tanto orais quanto escritos) a serem traduzidos (Projeto RECânone, 2019). Optamos, por materiais que expressem, de maneira reconhecidamente resumida, o trânsito entre as duas áreas às quais Zora mais dedicou-se a escrever - a Literatura e a Antropologia - além de materiais que levassem o leitor a conhecer a vida expressiva da autora (cartas e receitas escritas por Hurston e textos sobre sua a trajetória $)^{14}$ em uma variedade de atividades intelectuais e artísticas hoje reconhecidos nos currículos acadêmicos.

Como representantes de sua obra literária, o ensaio "Como Eu Me Sinto Sendo Uma Pessoa de Cor" [How it Feels to be Colored Me (1928)]

$14 \mathrm{Na}$ escrita do artigo, optou-se por adicionar uma referência à coletânea dos trabalhos feitos pelo projeto para não haver confusão entre referenciação de textos originais e de textos traduzidos. 
e o conto "Embebida em Luz" [Drenched in Light (1924)], publicados respectivamente nos jornais World Tomorrow e Opportunity, foram escolhidos por abrangerem características significativas da vida e escrita de Hurston.

"Como Eu Me Sinto Sendo Uma Pessoa de Cor" [How it Feels to be Coloured Me] é um pequeno texto de forte tom autobiográfico que discorre, em apenas quatro páginas, sobre a vivência da autora como uma mulher negra. Sendo um ensaio intimista, Zora relata como se descobriu negra: "eu lembro o dia exato que me tornei uma pessoa de cor" (p.1). O relato se debruça sobre as maneiras em que ela conviveu com os sentidos emergentes desta experiência durante sua vida. $\mathrm{O}$ fato singular deste ensaio, porém, não está na maneira como a autora descreve a sua experiência racializada, e sim como ela consegue expressar tal experiência desde dentro, na própria visão corporal da experiência como mulher e negra. Assim, o "ser" uma mulher negra é tido como dependente do reconhecimento disso através da percepção de si mesma em diálogo com outres. A partir do relato desta vivência de infância em Eatonville (cidade de origem da autora), Hurston nos dá algumas pistas sobre os processos reflexivos e de autoconsciência racial e de gênero que a tornaram uma mulher negra forte e confiante em meio a uma sociedade machista e racista.

O conto "Embebida em Luz" [Drenched in Li$g h t, 1995$ [1924]] apresenta uma narrativa que compartilha alguns dos elementos expressados no ensaio abordado acima. A narrativa pode ser entendida como uma representação das vivências de Zora Hurston quando criança, porém sob a perspectiva de Isis Watts, uma menina de onze anos. Assim como Zora em seu ensaio, Isis, no conto, considera o portão da casa o seu lugar favorito, pois é de onde pode observar o movimento das pessoas na estrada de onde as cumprimenta. Isis era facilmente reconhecida por todos pela sua alegria e pela sua vivacidade; a menina, embebida em luz, contagiava a todos que se aproximavam. "Música para Isis significava movimento. Em um instante, navalha e castigo esquecidos, ela estava fazendo uma fiel imitação da dançarina espanhola que havia visto em um show (...) algum tempo atrás. Os pés de Ísis eram talentosos - ela podia dançar praticamente qualquer coisa que via" (p. 5). A narrativa mostra a potência da felicidade de uma criança preta em um contexto familiar e social precário, reforçando a sua soltura e liberdade de expressão e existência. É importante remarcar que o conto é situado no contexto das maiores desigualdades raciais, no Sul de Estados Unidos, considerado como sendo um inferno para a população negra. A autora ainda escreve este conto na década de 1920, quando no país imperavam leis segregacionistas. Longe da autora negar a injustiça racial, a violência e o machismo, a escrita de Zora se detém nas formas de subjetivação, agência e resistência feminina, questões que irão ser debatidas pelo feminismos do Sul Global muitos várias décadas depois, em textos de Veena Das (2011), Saba Mahmood (2006), entre outras teóricas relevantes.

No texto "Prescrições de Doutores Raiz" [Prescriptions of Root Doctors] do ano 1935, Zora Hurston honra seu espírito etnográfico ao colher relatos diretos de receitas terapêuticas e medicinais utilizadas por médicos Hoodoo. ${ }^{15}$ Nesse curto texto podemos observar a riqueza de uma compilação de práticas realizada por Hurston no Sul dos Estados Unidos e que não foram higienizadas por um olhar eurocêntrico. Como as

15 O Hoodoo é uma forma tradicional de magia popular afro-americana praticada nas Américas. Seus praticantes são chamados de conjurers (conjuradores) ou rootwokers (raizeiros) 
seguintes alternativas de receita para curar unhas infestadas por fungos:

a) Tire a unha. Bata na ferida e tire dela todo o sangue que for possível. Então pegue um pedaço de bacon, um pouco de tabaco e uma moeda de um centavo e amarre-os à ferida. b) Tire a unha e leve ela até uma árvore verde que esteja do lado da saída do sol, e sarará . (p. 2, nossa tradução)

Assim, as rezas e os conjuros se combinam com plantas medicinais-venenosas, elementos animais e minerais. As receitas são redigidas com a indicação de quantidades necessárias a partir de referências corporais (uma mão cheia, a ponta de um dedo) e foi incluída detalhada informação sobre onde podem ser encontrados certos ingredientes nos mercados, seu custo incluso. Em sua estratégia de escrita de práticas de saúde, cuidado e magia popular, Zora se ocupa de trazer elementos de universos diversos para a vivência micro de curandeires e pacientes da medicina folk em um relato vivo, próximo e ciente da natureza híbrida destas práticas no contexto colonial e capitalista.

Além dos textos escritos por Zora, traduzimos também dois textos sobre Zora, com o intuito de nos valermos de uma maior quantidade de ferramentas para apreciar a produção da autora. Foi assim que escolhemos um texto escrito nos anos 1979 pela icônica Alice Walker; um texto contemporâneo, premiado dentro de um concurso dedicado a reconhecer trabalhos que sustentem perspectivas sobre feminismos plurais [The Gloria Anzaldúa Prize]. O segundo foi traduzido de forma coletiva a partir da autorização da autora, a estudiosa espanhola María Eugenia Cotera, e incluído dentro das nossas discussões. Apresentaremos ele mais adiante. Nos interessa agora nos determos na fundamental contribuição de Alice Walker.
O texto de Alice Walker (1975), Procurando Zora Neale Hurston [A Search for Zora Neale Hurston] nos remete à dura realidade vivida por Hurston em seus últimos anos de vida até o momento da sua morte. O esquecimento sofrido por Zora, tanto no que se refere aos seus textos literários quanto aos científicos, corroborou para sua morte na pobreza e no anonimato, e um enterro onde ela recebeu o tratamento de uma indigente na própria cidade natal, Eatonville. Alice Walker descreve em seu texto a viagem que ela pessoalmente fez à procura do túmulo da autora para que pudesse, enfim, ser identificado, treze anos após sua morte.

Em meio a essa busca, encontrava-se outra ainda mais intensa: a das memórias que a antropóloga tinha deixado no seu lugar de origem. Durante toda a narração, Walker se ocupa da ressignificação das raízes de Hurston, focando principalmente em Eatonville, cidade sobre a qual Zora escreveu diversos contos. Walker levanta, ainda, questões a respeito do impacto da presença da autora na cidade, o desafio do racismo sulista e a rígida hierarquização étnico-racial e de classe imperante, os dilemas da independência feminina, as tensões que surgem ao desvendar as raízes e práticas culturais corriqueiras na comunidade, junto com o orgulho interiorano que os moradores da cidade cultivavam. Além disso, o texto de Walker é extremamente pedagógico, destacando vários comentários de outres autores a respeito de Zora a fim de levar a nós leitores a entender o paradoxo que se reflete na importância da contribuição de Hurston dentro da Literatura assim como da Antropologia e o simultâneo apagamento da autora dentro desses mesmos cenários.

A inventividade de Hurston foi múltipla e não se ateve à produção de textos escritos. Ela produziu também filmagens no tempo em que 
seus contemporâneos antropólogues Margaret Mead e Gregory Bateson começaram a desenvolver vídeos curtos durante seus trabalhos de campo (El Guindi, 2015). Porém, enquanto que o casal Mead-Bateson foi registrado na história da antropologia como sendo pioneiro no método, e portanto referência dentro da área, o trabalho dos vídeos filmados e narrados por Hurston foi ignorado. Foi assim que, com a intenção de refazer a memória desta importante subárea da Antropologia como é a Antropologia visual, foram realizados alguns trabalhos de legendagem de materiais audiovisuais. Legendamos um vídeo (1'30") onde Zora performa, canta e analisa a manifestação norte-americana da Dança do Corvo e traça uma hipótese sobre sua influência africana; e de outro vídeo (6'45") gravado por ela em 1928 , no qual observamos uma série de cenas da vida cotidiana que ela descreve enquanto conta piadas, canta músicas populares que, segundo narra, "a sua avó lhe ensinou a cantar", convidando aos ouvintes a inventar os últimos trechos das músicas de acordo com as frases que elas acharem mais adequadas.

A partir da elaboração destes materiais, o projeto RECânone apostou nos processos de difusão dos textos traduzidos. Entre outras atividades, foi realizado o I Encontro RECânone "Zora nos Corredores" se realizou na Semana da Consciência Negra, no final de novembro de 2019. Foram instaladas mesas em um dos corredores externos do Setor de Aulas II do Centro de Ciências Humanas, Letras e Artes, na UFRN. Lá foram exibidos e comentados livros escritos por mulheres negras trazidos de forma colaborativa das bibliotecas das nossas próprias casas. Realizamos também a exibição dos vídeos legendados assim como dos materiais traduzidos e dos produtos realizados a partir da reinterpretação de sua obra: cordéis, fanzines, cesta de citações e gibis. Também foi realizada uma oficina de stencil de camisetas com algumas imagens do cordel e logo do projeto que foram desenvolvidos ao longo do semestre.

A atividade, performada de maneira lúdica, expandiu seu alcance a alunes, professores e demais pessoas que circularam no corredor do setor de aulas CCHLA naquele dia, despertando a curiosidade e reflexão acerca das obras de Zora, bem como sobre as práticas acadêmicas de legitimação de conhecimentos tidos como universais, colocando em pé de discussão o direito de poder falar, representar e de produzir conhecimento num viés rizomático e inclusivo. Foram confeccionadas receitas culinárias que tínhamos traduzido, fazendo possível degustar o bolo de chocolate que Zora recolhe nas suas notas etnográficas (1935) assim como uma limonada típica dos contextos suburbanos da Flórida dos anos 1930.

A vivência sensorial foi tratada num patamar próximo da experiência cognitiva de alunes e docentes, ao mesmo tempo em que a criação artística a partir do que as traduções nos geraram foi colocada no nível da produção propriamente técnica dos textos, em uma proposta de tradução intersemiótica. Sabemos que, ainda quando nas maquinarias acadêmicas da produtividade sejam contabilizadas apenas as produções técnicas e os conteúdos produzidos, o processo exalou uma série de vivências que nos colocaram em um lugar ativo, criativo e desafiador das estruturas colonizadoras do saber, ressignificando o espaço dos corredores universitários que se tornaram um meio de publicação dos materiais produzidos durante o semestre.

\section{A recepção de Zora em sala de aula}

Uma educação libertadora fornece diversas possibilidades em que os sujeitos possam enxergar a história, o seu próprio tempo e os outros sujeitos, ampliando-lhes a visão de 
mundo, enxergando as diversas contradições. Segundo Paulo Freire:

[Nós, enquanto que] seres histórico-sociais, nos tornamos capazes de comparar, de valorar, de intervir, de escolher, de dialogar, de decidir, de romper, por tudo isso, nos fizemos seres éticos. Só somos porque estamos sendo. Estar sendo é a condição, entre nós, para ser. Não é possível pensar os seres humanos longe, sequer, da ética, quanto mais fora dela. (Freire, 1996, p. 33)

A condição dialética humana de ser sendo postulada por Paulo Freire, é medular para que possamos ter uma noção das contradições que nos rodeiam. Contradições de interesse entre autores, contradições entre literaturas, entre as próprias linhas epistemológicas da produção do conhecimento. Desta maneira, trazer à tona a epistemologia de autores esquecides é uma forma concreta de remar contra a maré constante do epistemicídio (Carneiro, 2005), fornecendo às Ciências Sociais o conhecimento de autores desconhecides, mas cujas contribuições avaliamos hoje como sendo de grande magnitude.

O ambiente da sala é um contexto para o desenvolvimento dialogado do conhecimento. Reconhecendo esse pressuposto, o trabalho com Zora Hurston na disciplina Teoria Antropológica I para o curso de Ciências Sociais na UFRN durante o semestre 2019.2 promoveu o engajamento des alunes na produção de ensaios que abordassem a biografia e a produção acadêmica de Zora Hurston a partir de uma perspectiva interseccional. Os diálogos críticos e as produções ali registradas serviram à docente e discentes como escadas provisórias para observar os horizontes do mundo da vida para além do grande muro do cânone.

Uma das integrantes do projeto, a Profa. Ana Gretel, ministrou durante o semestre 2019.2 a disciplina Teoria Antropológica I. Ali foram realizados, em diálogo entre espaços de ensino e extensão, alguns exercícios de apropriação da obra de Hurston a partir de leituras dos textos recentemente traduzidos. Nesta disciplina, a metodologia e bibliografia propostas abriram um espaço para que os e as discentes conhecessem outres autores para além daqueles nomeados e privilegiados pela episteme hegemônica (Branco et al., 2018).

Estudantes acolheram a proposta refletindo sobre as formas em que o curso de ciências sociais, assim como os cursos que formam o conhecido campo das humanas, carrega em sua formação um discurso que deslegitima e apaga o pensamento, voz e produção de determinados grupos sociais que foram e continuam sendo há muito tempo subalternizados. Nesse sentido, Djamila Ribeiro (2019, p. 55), analisando a noção foucaultiana de discurso, afirma que não devemos pensar nele como um simples amontoado de palavras ou concatenação de frases, mas sim que ele é um sistema que estrutura determinados imaginários sociais histórica e socialmente situados.

Deste modo foi que ensaios teóricos, histórias em quadrinhos, cordéis e fotomontagens foram criados no intuito de fazer diversas releituras da contribuição de Hurston. Destacamos a elaboração de Fernandes dos Santos et al. (2019) da narrativa da novela "Seus olhos viam Deus" a partir do uso de técnicas diversas como a performance, fotografia, histórias em quadrinhos e técnicas audiovisuais, na consecução de um produto audiovisual leve, divertido e que é expressivo da receptividade deste grupo em particular e da turma em geral.

O problema do epistemicídio, denunciado contemporaneamente (Carneiro, 2005) já era exposto criticamente por Zora desde as próprias turbulências da sua vida acadêmica, confrontando a forma pela qual as pessoas negras 
estadunidenses eram representadas na literatura e, ainda, como era a realidade des pesquisadores negres enquanto sujeites produtores de saber, coisa que é abarcada com excelência no texto O Sistema do Negro de Estimação [The Pet Negro System].

Apresentar Zora em sala de aula permitiu-nos vivenciar a prática de uma micro justiça epistêmica na reivindicação da fala de uma antropóloga, artista e folclorista que foi apagada, não acidentalmente, por esse mesmo racismo estrutural e epistêmico denunciado por ela décadas antes. A experiência vivenciada pela turma e por participantes do projeto enriqueceu o debate acerca da necessidade de se pensar numa teoria que se alie à prática dialeticamente, bem como onde o questionamento e pensamento crítico sejam estimulados cada vez mais sustentando um olhar descolonizador sobre essas produções, para que assim essas pessoas que foram e são silenciados até hoje pelo cânone possam passar a ser sujeitas ativas, visto que se trata não apenas de "falar" ou ser representades nos textos, mas também da própria possibilidade de existir.

Grada Kilomba (2019, p. 41) afirma que há um medo apreensivo de que, se o sujeito colonial falar, o colonizador terá que escutar. Ele(a) seria forçado a um confronto desconfortável com as verdades des "Outres". Verdades que foram negadas, reprimidas e mantidas em silêncio, como segredos. Segredos como a escravidão, o colonialismo e o racismo. As atividades realizadas em sala de aula favoreceram a comparação de perspectivas, entendendo-se que há um mundo vasto, repleto de conhecimentos e nuances fora do que temos constantemente perpetuado como ciência, sustentado pelo cânone. O despertar da curiosidade, das dúvidas e do próprio interesse humano no enxergar das diversas possibilidades que rodeiam as contradições é auxiliar na defesa da existência de uma diversidade epistêmica.
O projeto RECânone procura desarticular os dispositivos de despersonalização na tradução, trabalhando simultaneamente na obra e na sensibilidade cultural que permite a sua recepção, na trajetória biográfica da pessoa traduzida e o efeito que o conhecimento desta vida gera nos entornos de formação, incorporando o conjunto da obra autoral ao repertório cultural próprio das nossas comunidades, que abraça processos culturais múltiplos como o cordel, o texto acadêmico e a interpretação teatral. As genealogias próprias (Anzaldúa, 1987) nos permitem libertar a imaginação do prisma da modernidade decimonônica. Podemos dizer que a equipe embarcou na construção de uma genealogia própria, à procura de exercer o direito "a ter um nome" através do estudo e tradução de figuras autorais que façam sentido para nossa comunidade de estudantes, especialmente àqueles pertencentes a setores sociais vulnerabilizados.

\section{Traduzir para analisar: pontos chave na obra de Zora Hurston}

Um dos desafios do projeto tem sido a barreira linguística, considerando que estudantes de graduação do nordeste, tanto das capitais quanto do interior têm acesso relativamente escasso à língua hegemônica no mundo acadêmico, que é o inglês. Nesse contexto, a linguagem dominante pode ser utilizada como forma de manutenção de poder, uma vez que exclui pessoas que foram marginalizadas de um sistema educacional justo (Ribeiro, 2019, p. 25). Assim, a qualidade técnica das traduções foi garantida nos apoiando nas ferramentas analíticas ativadas como recursos por participantes no projeto que já estão formades e em processo de formação nesse campo. Porém, temos considerado nossas traduções como peças cujo valor emerge não só da sua potência teórica, de seu preciosismo técnico ou ainda da sua "autonomia estética" (Bloom, 1995), mas também, e de forma medular, do 
seu vínculo cultural, social e político com os contextos nos quais elas foram produzidas. Também nos ocupamos de realizar uma tradução sensível ao contexto de recepção, com notas de rodapé explicitando conceitos que podiam permanecer confusos, ressaltando os poucos - mas verdadeiramente existentes - casos nos quais não compreendemos o que a autora quis dizer. Temos refletido sobre o sentido da escolha de cada texto, ao mesmo tempo em que projetamos algumas condições para que estes textos fossem lidos e relidos, recontextualizados, citados, estudados e potencializados em novas aproximações teóricas, etnográficas e literárias de índole local de modo que, para usar a metáfora da própria Zora, pudéssemos encher de luz os cinzentos corredores acadêmicos, tanto quanto os itinerários formativos de nossos leitores.

Pensar na obra de Zora Hurston é refletir sobre a produção de uma sujeita que, havendo transitado pela ficção, também o fez pela ciência antropológica na sua vertente etnográfica, compilando os saberes da oralidade (à maneira da lenda de John Henry, compilada em Mules and Men, de 1935), colhendo narrativas locais sobre saúde popular (à maneira das Prescriptions of Root Doctors, de 1935). Ao mesmo tempo, Zora não se poupou de falar em temas urgentes, como a reflexão crítica sobre o racismo intelectual em formato ensaístico na escrita de The Pet Negro System, do ano 1943. A produção de Zora é diversa, radical, colorida. O trabalho das traduções coletivas nos incitou a desenvolver novos olhares sobre a autora e levantar uma série de questionamentos de tipo narrativo, científico e epistemológico.

Acreditamos que há uma importante revisão histórica a ser realizada da forma em que a antropologia cultural norte-americana tem reagido perante as propostas de Hurston. Longe de serem incorporadas e problematizadas dentro do projeto maior desta disciplina, houve um silenciamento e uma marginalização da obra de Hurston cuja genealogia crítica merece ser reconstruída. Nosso trabalho tentou desempoeirar, no sentido de trazer para o uso cotidiano um dispositivo esquecido em algum baú da casa da antropologia, algumas estratégias significativas da escrita de Zora Hurston nas fronteiras entre a antropologia, a performance artística e a produção literária. Fizemos isso com o cuidado que requer lidar com a delicadeza da reconstrução deste tipo de material, e estamos prestes ao aprimoramento destas metodologias situadas e cuidadosas de reconstrução genealógica.

María Cotera (2008) descreve a experiência de três autoras mulheres, pertencentes a três grupos etnicamente diferenciados: Ella Deloria, de ascendência indígena; Jovita González, de ancestralidade chicana [mexicana] e finalmente a afrodiaspórica Zora Neale Hurston. Dos casos analisados, o de Hurston manifesta seu caráter excepcional no que diz respeito a um aspecto específico: ela alcançou um status acadêmico atípico para mulheres racializadas como não brancas na época, enquanto de acordo com o paradoxo antes mencionado, o efeito da sua produção dentro do cânone acadêmico da época resultou ser muito menor do esperável em virtude do mérito alcançado pelo seu trabalho. Isto nos traz, rapidamente para a consideração de que o acesso não se resolve somente com o ingresso nessas instituições, mas também com a possibilidade de fazer redes, dialogar no marco de interlocuções significativas e, finalmente, conseguir se identificar subjetivamente com esses espaços, garantindo a própria permanência neles.

Cotera relata como, através da análise comparativa de correspondências enviadas entre Franz Boas e alguns de seus alunes, Zora recebeu muito menos atenção do que as "estrelas" da 
escola, especialmente Ruth Benedict e Margaret Mead, por parte do mestre (Cotera, 2008). A autora mede a proficuidade da comunicação entre Hurston e Boas a partir da quantidade e do teor das correspondências enviadas entre o mestre e seus alunes. E essa análise demonstra que a comunicação era escassa, tanto em termos de intercâmbios de fato quanto em termos do grau de intimidade impregnado na escrita dessas cartas. Assim mesmo, a comunicação de Hurston com outres colegues da antropologia era escassa. Desta forma, observamos que, apesar de ela pertencer a uma prestigiosa instituição científica, um vazio foi criado ao redor do seu trabalho. O seu intercâmbio com interlocutores significativos, como vimos no tópico anterior, permaneceu fortemente ligada ao movimento cultural e dos direitos humanos do Harlem Renaissance mais do que à própria antropologia. Talvez tenha sido por isso que Zora é lembrada hoje como um ícone da literatura norte-americana, mas não como a antropóloga criativa, crítica e audaz que ela foi.

É importante destacar, também, que a ordem eurocêntrica do conhecimento advém de um sistema de relações desiguais de poder de "raça", e que qualquer forma de saber que não se enquadre nesta ordem é rejeitada. O sistema acadêmico hegemônico construído em um espaço de e para brancos emudece as vozes daqueles que foram subalternizados, desqualificando suas produções e conhecimentos, num processo de silenciamento e apagamento, delimitando que aquele espaço não the cabe, "a confirmação de que não há espaço onde colonizadas/os podem falar" (Kilomba, 2019, p. 53).

Colocaremos aqui as pontas de alguns fios que consideramos chave para uma análise decolonial da obra desta autora e que podem nos ajudar a questionar o caráter eurocêntrico da antropologia que performamos na academia. Tais considerações pretendem criar laços de afeto e identificação entre a obra de Zora Hurston e o coletivo de antropólogues brasileires e latino-americanes em geral: antropólogues negres, indígenas e, de forma mais ampla, aqueles que provêm das comunidades que se dedicam a pesquisar - aqueles que cultivam a necessária antropologia feita em casa e representativa em termos de lugares de enunciação. Mais em cima citamos alguns aspectos chave da obra de Zora Hurston, a saber: antropologia como crítica cultural, apagamento das fronteiras entre gêneros textuais, conhecimento corporificado e situado, descentramento a respeito do logocentrismo, questionamento radical da dicotomia sujeito-objeto, reconhecimento da provisoriedade das produções científicas, visibilização de epistemologias situadas em pontos de vista - standpoint epistemologies, diálogo aberto entre ciência e produção cultural. Para os fins deste artigo, gostaríamos de nos determos somente no ponto que diz respeito ao apagamento entre os gêneros textuais da literatura e da antropologia, pois ele se manifestou como uma constante inquietação ao longo do trabalho de tradução dos textos de e sobre Zora Hurston.

Zora colhia relatos da própria comunidade para reinterpretá-los, muitas vezes, de forma livre e aberta. Concordando com a ideia de que "quem conta um conto aumenta um ponto", a maior parte da obra de Zora se encontra situada em uma área intersticial entre os gêneros onde não há uma delimitação explícita entre "verdade objetiva" (terreno legitimado pela "ciência antropológica") e "construção ficcional" (espaço cabível à literatura). Os esforços de verossimilhança na descrição dos dados de campo são colocados em segundo plano para privilegiar a expansão dos fatos da cultura "para além dela", estimulando leitores e ouvintes para somar seu ponto no bordado das práticas colhidas.

Assim, em um vídeo onde ela realiza várias capturas de seu trabalho de campo na Flórida 
rural (Hurston, 2019), ela sugere "inventar" partes de uma música cujos detalhes assume não lembrar: "não sei quem me contou essa música, eu ouvi essa música no meu povoado de origem quando eu era uma criança (...) eu vou chamar esse verso de (...), mas você pode pegar qualquer verso e customizá-lo" (2019: 2'45'). Preenchendo o sentido mais antigo da ideia de "mito", Hurston compreendia as histórias do folclore do seu próprio povo não como "mentiras", mas como imaginações com peso social onde as narrativas tinham o trabalho, por si próprias, de serem construtoras de verdade e performadoras de práticas.

Acreditamos que o trabalho científico de Zora tenha sido relegado ao ficcional, e que o ficcional atuou, neste caso, como uma prisão. Entendemos aqui o espaço do ficcional como um território cativo em um sentido bem específico: as ficções, com seu poder único de imaginar o individual junto com o social, com a possibilidade de macerar distopias, absurdos e sistemas bizarros comparáveis ao real através da metáfora, da hipérbole ou da ironia, possuem um potencial altamente libertador. Porém, no que diz respeito ao contexto específico da recepção da obra de Zora na ciência antropológica, o ficcional tem sido o gueto ( $\mathrm{e}$ fazemos um uso bem consciente desse termo, com suas evidentes implicações sócio-históricas) onde a produção de conhecimento da autora foi relegada.

\section{Conclusões: a tradução como tarefa de reparação epistêmica}

"Não quero uma literatura que deprecia meu trabalho"

Oyeronke Oyegumi, 1988 (como citada em Mudimbe, 2013 [1988]).

Nas últimas décadas, o incremento na presença de novos atores - estudantes negros e negras, quilombolas, indígenas, dentre outres, trouxe novos olhares e perguntas fortalecidas, enriquecendo com esses questionamentos o campo das humanidades e das ciências sociais. Dentro dessas perguntas se encontra, de forma central, a procura pela bibliografia de autores negres e outros elementos que as constituem pelas genealogias intelectuais da diáspora africana, indígena e latina.

"Não quero [1er] uma literatura que deprecia meu trabalho", foi a resposta que a socióloga nigeriana Oyeronke Oyegumi deu a seu orientador quando ele insistia para que Oyeronke abordasse a biblioteca colonial (Mudimbe, 2013 [1988]) para elaborar o famoso "Estado da Arte" que se coloca como prerrogativa à toda pesquisa. É preciso questionar essas práticas e criar novas. Procuramos o diálogo Sul-Sul como uma estratégia de reciprocidade, atendendo à novas formas de atenção ao que é potencialmente libertador. Porque tanto como precisamos falar, precisamos escutar. Não se trata somente de "criticar" o conhecimento eurocentrado e heteronormativo para continuarmos imerses nele: precisamos reconstruir o itinerário que até aqui nos trouxe, considerando o significado talhado sob a forma do silêncio histórico e cultural. Parafraseamos Glória Anzaldúa (2012 [1987]), quando no seu último capítulo de "Borderlands. La Frontera: The New Mestiza", propõe (re)existir na criação de novas genealogias culturais.

A partir da contribuição de autoras como Zora Neale Hurston é que nutrimos nossa teoria e nossa prática, voltando às suas produções para procurar respostas em nossos tempos embrutecidos. No decorrer do trabalho, fomos nos tornando afetiva e intelectualmente mais próximes à obra de Zora, dialogando com ela em vários níveis e restituindo, na experiência, uma parte da escuta intelectual que a academia do seu tempo lhe negou. A prática da escrita de 
Zora Neale Hurston foi marcada pela resistência e confronto aos poderes estabelecidos dentro e fora da academia: Zora tinha o conhecimento de que se tratava de dar voz à sua própria comunidade cuja sobrevivência estava ameaçada por genocídios e epistemicídios sistêmicos.

Conforme anuncia Ribeiro (2019, p. 42), quando pessoas negras estão reivindicando o direito de ter voz, de serem sujeites, elas reivindicam, ao mesmo tempo, o direito à própria vida. Assim como tantas outras autoras negras, Hurston abriu novos caminhos para pensar e exercer a antropologia a partir de um lugar potencialmente libertador. A leitura desta autora poderia ter sido chave interpretativa para referência de etnógrafos e etnógrafas das seguintes gerações, particularmente em contextos onde os temas que se estudam fazem parte da dinâmica social das próprias comunidades. Hoje, das universidades do nordeste brasileiro, situades nesse cruzamento de caminhos geo-temporal do ano 2020, nos alenta recuperar a obra desta autora, rica em escrevivências (Evaristo, 2006) e, como tradutoras e comentaristas, nos destinamos nossos trabalho à sua efetiva reinscrição na genealogia de pensamento antropológico, com ela reivindicando processos de escuta, leitura, tradução, ensino e criação radicalmente libertadores.

\section{Agradecimentos}

Gostaríamos de agradecer à antropóloga Nicole Washburn pelas suas revisões qualificadas desde o sul dos Estados Unidos; ao Prof. Rafael Antunes Almeida pela organização da Oficina Recânone na UNILAB, à doutoranda em Antropologia Peti Mama Gomes pelo apoio com informações específicas sobre a comunidade de Estudantes Africanos na UNILAB, ao Sócio-Antropólogo Dr. Pingréwaoga Béma Abdoul Hadi Savadogo pela revisão do resumo em francês, à filósofa e tradutora Caterina Rea pelas orientações e à Prof $^{a}$. Denise Costa pelo estímulo e fornecimento de bibliografias para serem traduzidas pelo projeto. Integrantes do Projeto RECânone: Sandra F. Erickson, Tânia Lima, Fernanda F. do Nascimento, Maria Clara F. dos Santos, Pábllo E. Viana Pereira, Pablo S. Lisboa, Thiago J. Nascimento, Uriell B. Gomes Costa, Marie Castanheda, Victória D. Barbosa, Vinicius C. Chaves, Natalia Cabanillas e Ana Gretel Echazú B. Agradecemos aos seguintes discentes do curso de Ciências Sociais a sua colaboração no I Evento RECânone - Zora Nos Corredores: Juliana Mytzi, Victoria Regia S. de Moura, Clístenes E. da Silva Costa, Taizia T. Dos Santos, Elton C. Barbosa. Estamos gratas à colaboração do arteativista Pedro I. Barros Castro na Oficina de Stencil sobre Zora Hurston.

\section{Referências}

Akotirene, C. (2018). O que é interseccionalidade? Letramento.

Anzaldúa, G. ([1987] 2012) Borderlands, La Frontera: The new Mestiza. Aunt Lute Books.

Appiah, K. A. (2000). Thick translation. Em L. Venuti (Ed.), The Translation Studies Reader ( pp. 417-429). Routledge.

Asad, T. (1996) A comment on translation, critique, and subversion. Em A. Dingwaney \& C. Maier (Eds.), Between languages and culture: Translation and cross cultural texts (pp. 32531). University of Pittsburgh Press.

Assunção da Silva, L., \& Fernandes de Souza, E. (2017). A epistemologia do barraco: uma breve história do movimento LGBT em geral. Inter-Legere, 1(21), 106-121.

Bhabha, H. (1994). The location of culture. Routledge.

Bloom, H. (1995). O cânone ocidental. Objetiva. Bourdieu, P. (1986). L'illusion biographique. Actes de la Recherche en Sciences sociales, 6263, 69-72. 
Benjamin, W. (1999[1923]). The task of the translator. Em L. Venuti (Ed.), The translation studies reader (pp. 15-25). Routledge.

Branco, L.; Souza Bezerra, C; Flores, E.; Rodrigues Bezerra; T. dos Reis, I., Echazú Böschemeier, A.; Cabanillas, N. (junio, 2018). A escrita feminina nos "clássicos" antropológicos do Sul: Uma reflexão anticânone. Epistemologias do Sul, 2(1), 66-100. https://revistas.unila.edu.br/epistemologiasdosul/article/view/867

Butler, J. (2018). Corpos em aliança e a politica das ruas: Notas para uma teoria performativa da assembleia. Civilização Brasileira.

Carneiro. A. S. (2005). A construção do outro como não-ser como fundamento do ser (Tese de Doutorado). Universidade de São Paulo, São Paulo, SP, Brasil. https://negrasoulblog. files.wordpress.com/2016/04/a-construc3a7c3a3o-do-outro-como-nc3a3o-ser-como-fundamento-do-ser-sueli-carneiro-tese1.pdf.

Carvalho, J. (2018). Encontro de Saberes: por uma refundação étnica, racial e epistêmica das universidades brasileiras. Em J. Bernardino-Costa, N. Maldonado-Torres e R. Grosfogel (Orgs.), Decolonialidade e pensamento afrodiaspórico. Autêntica.

Clifford, J., \& Marcus, G. (Eds.). (1986). Writing culture: the poetics and politics of ethnography. University of California Press.

Connell, R. (2012). O Império e a criação de uma ciência social. Contemporânea, 2(2), 309-336. http://www.contemporanea. ufscar.br/index.php/contemporanea/article/view/85/50

Connell, R. (2019). Cannons and colonies: the global trajectory of sociology. Estudos Históricos, 32(67), 349-367. https://doi. org/10.1590/s2178-14942019000200002

Crenshaw, K. (1991). Mapping the margins: intersectionality, identity politics, and violence against women of color. Stanford
Law Review, 43(6), 1241-1299. https:// doi.org/10.2307/1229039.

Cotera, M. E. (2008). Lying Up a Nation: Zora Neale Hurston and the Literary Uses of Folk. Em M. E. Cotera, Native Speakers: Ella Cara Deloria, Zora Neale Hurston, Jovita Gonzalez and the poetics of culture. University of Texas Press.

Das, V. (2011). O ato de testemunhar: violência, gênero e subjetividade. Cadernos Pagu, (37), Julho-Dezembro (pp. 9-41). Campinas.

Davis, H., \& Todd, Z. (2017). On the importance of a date, or decolonizing the Anthropocene. ACME: An International Journal for Critical Geographies, 16(4), 761-780. https://www.acme-journal.org/index. $\mathrm{php} / \mathrm{acme} / \mathrm{article} / \mathrm{view} / 1539$.

Domingues, P. (Nov. 2017). O moisés dos pretos: Marcus Garvey no Brasil. Novo Estudo - Cebrap, 36(3), 129-150.

Echazú Böschemeier, A. G., Reis, I., Cabani1las, N., Rodríguez Sierra, O., Vilas Boas, M. J., \& Greco, L. (2017). Feminizing the canon: Classics in anthropology from the perspective of female authors. Teaching Anthropology - A Journal of the Royal Anthropological Association. https://www.teachinganthropology.org/resources/

Echazú Böschemeier, A. G. (2019). Crítica ao Cânone na Antropologia. [Arquivo de vídeo] https://www.youtube.com/watch?$\mathrm{v}=$ BX_JSz0hm1c

El Guindi, F. (2015). Visual anthropology. In R. Bernard, \& C. Gavlee, Handbook of Methods in Cultural Anthropology (pp. 439463). Roman \& Littlefield.

Eriksen, T., \& Nielsen, F. (2001). A history of Anthropology. Pluto Press.

Evaristo, C. (2006). Becos da Memória. Mazza.

Fernandes dos Santos, M. C., Silva, J. F., Silva, R. P., Tavares, G. C., \& Marinho de Melo A. I. (2019, Novembro 20). Narrativa de Seus olhos viam Deus, de Zora Neale 
Hurston. [Arquivo de vídeo] ://www.youtube.com/watch?v=jDoRg1JZujI

Foucault, M. (2006). O que é um autor? (6 ${ }^{\mathrm{a}} \mathrm{ed}$.). Vega.

Freire, P. (1996). Pedagogia da Autonomia. São Paulo: Paz e Terra.

Geertz, C. (1988 [2005]). Obras e vidas: o antropólogo como autor. EDUFRJ.

Ginzburg, J. (2004). Cânone e valor estético em uma teoria autoritária da literatura. Revista de letras, 44(1), 97-111.

Gomes, N. L. (2017). O movimento negro educador: Saberes construídos na luta por emancipação: Vozes.

Gonzales, L. (1980, outubro). Racismo e sexismo na cultura brasileira. Encontro Anual da Associação Nacional de Pós-graduação e Pesquisa em Ciências Sociais, Rio de Janeiro, RJ, Brasil, 4.

Hill Collins, P. (2015). Em direção a uma nova visão: raça, classe e gênero como categorias de análise e conexão. In R. Moreno (org.), Reflexões e práticas de transformação feminista (pp. 13-42). soF.

hooks, b. (2019). Erguer a voz: pensar como feminista, pensar como negra. Elefante.

Hurston, Z. N. (2002). Seus olhos viam Deus (M. Santarrita, Trad.). Record.

Hurston, Z. N. (2019). O que os editores brancos não publicarão (M. Basques, Trad.). Ayé: Revista de Antropologia, 1(1), 102-111. Recuperado de http://www.revistas.unilab.edu.br/index.php/Antropologia/article/view/288

Hurston, Z. N. (2019, Novembro 21). Pesquisa de campo de Zora Neale Hurston - 1928. [Arquivo de vídeo] https://www.youtube. com/watch? $v=a j X o 8 I v E B D M$

Hurston, Z. N. (2019, Setembro 7): Zora Hurston canta "A Canção do Corvo" (Crow Dance). [Arquivo de vídeo] https://www.youtube.com/watch?v=Kil-dt-Dhb4
Hurston, Z. N. (1995 [1924]). Drenched in Light. In Z. N. Hurston, Novels and stories (pp. 940-948). The Library Of America.

Hurston, Z. N. (1995). How It Feels To Be Colored Me. Em Z. N. Hurston, Folklore, memoirs, and other writings (pp. 826-829). New York: The Library Of America.

Hurston, Z. N. (1943) The 'Pet Negro' System. American Mercury, 56, 593-600.

Hurston, Z. N. (1935). Prescriptions of Root Doctors. Em Z. N. Hurston, Mules and men (pp. 281-285). Harper \& Collins Ebooks.

Instituto Nacional de Estudos e Pesquisas Educacionais Anixio Teixeira (INEP). (2018). Censo da Educação Superior. Notas Estatísticas. Brasília.

Kilomba, G. (2019) Memórias da plantação Episódios de racismo cotidiano (J. Oliveira, Trad.). Cobogó.

Laist, R. (2009). The self-deconstructing canon: teaching the survey course without perpetuating hegemony. Currents in Teaching and Learning, 1(2), 50-57.

Mahmood, S. (2006). Teoria feminista, agência e sujeito: algumas considerações sobre o revivalismo islâmico em Egipto. Etnográfica, $X(1), 121-158$.

Malinowski, B. (1989 [1967]). A Diary in the strict sense of the term. Stanford University Press.

Merriam Webster News. (2020). Merriam-Webster's words of the year 2019: They, plus quid pro quo, crawdad, exculpate, and 7 more of our top lookups of 2019. https:// www.merriam-webster.com/words-atplay/word-of-the-year

Mendoza, B. (2019). La colonialidad del género y del poder. De la poscolonialidad a la decolonialidad. Em K. Ochoa (coord.), Miradas en torno del problema colonial. Pensamento anticolonial e feminismos descoloniales en los sures globales (pp. 35-71). Akal. 
Mignolo, W. (1991). Canon and cross-cultural boundaries. Or, whose canon are we talking about? Poetics Today, 12(1), 1-28.

Mohanty, C. T. (1984). Under Western eyes: Feminist scholarship and colonial discourses. Boundary 2, 12(3), 333-358. https://do.org/10.2307/302821

Mudimbe, V. Y. (2013 [1988]). A invenção de África. Gnose, filosofia e a ordem do conhecimento. Ramada \& Luanda: Edições Pedago.

Mukherjee, A. (2010) What is a classic? International literary criticism and the classic question. PMLA, 125(4), (pp. 1026-1042). https://doi.org/10.1632/ pmla.2010.125.4.1026

Organização das Nações Unidas - ONU(2009 [1948]). Declaração Universal dos Direitos Humanos. https://nacoesunidas. org/wp-content/uploads/2018/10/ DUDH.pdf

Pinheiro, V. R. (2019). Entre Áfricas e Ocidente: A formação cânone literário em Moçambique. Alcance Editores.

Projeto RECânone (2019). Zora Neale Hurston: Leituras da América do Sul / Readings from South America. Compilação no prelo.

Quintero, P. (2019). Yo, tú, elle, nosotres, vosotres, elles. El lenguaje inclusivo: ¿tiene algo que ofrecer? https://www.psyciencia.com/lenguaje-inclusivo-investigaciones/

Reis, R. (1992) O que é o cânon. Em J. L. Jobim (Org), Palavras da crítica. Imago. (pp. 1-17). https://social.stoa.usp.br/arti-
cles/0037/3007/C_NON_-_roberto_reis. pdf

Rivera Cusicanqui, S. (2010). Ch'ixinakax utxiwa. Una reflexión sobre prácticas y discursos descolonizadores. Tinta Limón.

Ribeiro, D. (2019). Lugar de fala. Pólen.

Silva, J. Costa e V. Melo (1ro fev. 2018). A Unilab e o desmonte da educação pública. Le Monde diplomatique, Edição 127 Brasil. https://diplomatique.org.br/unilab-e-o-desmonte-da-educacao/

Sousa Santos, B. (2010). Para além do pensamento abissal: das linhas globais a uma ecologia dos saberes. Em B. Sousa Santos \& M. P. Meneses (Eds.), Epistemologias do Sul (pp. 31-83). Cortez.

Spivak, G. (2000). The politics of translation. In L. Venuti (Ed.), The translation studies reader (pp. 397-416). Routledge.

Spivak, G. (2010). Pode o subalterno falar? Editora da UFMG.

Sun Park, E. (2020). Why I left Academia: philosophy's homogeneity needs rethinking. http://read.hipporeads.com/ why-i-left-academia-philosophys-homogeneity-needs-rethinking/

Walker, A. (1975). In search of Zora Neale Hurston. Ms. Magazine.

Wasserman, B. D., \& Weseley, A. J. (2009). Qué? Quoi? Do languages with grammatical gender promote sexist attitudes?, Sex Roles, 61, 634-643. https://doi. org/10.1007/s11199-009-9696-3

Como citar este artigo: Echazú, A., Cabanillas, N., Erickson, S., Barbosa, V., do Nascimento, F., da Costa, M. e Cavalcanti, F. (2020). A tradução de Zora Neale Hurston para o cânone antropológico: práticas de extensão desde uma perspectiva feminista e interseccional. Mutatis Mutandis. Revista Latinoamericana de Traducción, 13(2), 228-254. https://doi.org/10.17533/udea. mut.v13n2a02 